特集 『生態系アセスメントの課題 一景観生態学からのアプローチー』

\title{
ダム建設と生態系アセスメント
}

\author{
日笠 睦
}

広島大学大学院国際協力研究科 739-8529 東広島市鏡山 1-5-1 (mutsumi@hiroshima-u.ac.jp)

\section{Dam construction and its environment impact assessment to ecosystems Mutsumi HIKASA}

Graduate school for International Development and Cooperation, Hiroshima University, Kagamiyama, HigashiHiroshima, 739-8529 Japan

はじめに

ダム事業の特徵として, 陸域·水域ともに影響を 及ぼすことが挙げられる。陸域と水域では生息す る生物相も環境基盤も大きく異なり，ダム事業に おける環境アセスメントでは, 陸域と水域に調査 区を分けて評価を行うことになる(島谷, 2000).ダ ム事業による環境への影響も，堤体建設や付替道 路の新設といった直接的なものや，構造物が存在 することによる継続的影響，さらには洪水調節や 湛水による水流の变化などの間接的な影響など, いくつか影響の空間的範囲や継続時間が異なるも のが想定され，それぞれで区別して調査・予測を行 うこととされている（河川事業環境影響評価研究 会, 1999)。これは，建造物による影響は陸域・水 域ともに考えられるが，洪水調節などによる間接 的な影響は主として水域，しかもダム堤体付近だ けではなくかなり下流まで影響が及ぶと思われる ためである。

また新アセス法においては, 生態系の評価軸と して上位性・典型性·特殊性などを基準とした注目 種が挙げられている(環境庁企画調整局, 1999).あ る一つの種（実際は個体群）について，そのハビ タットの生物・非生物環境の現況を調査し, 既存の 研究事例などを参考に，事業によるハビタットの 改変とその影響を予測するという方法である。こ のような視点での「生態系」は様々な空間スケール のものが存在する。例えば植物を対象とした場合, 陸域では殆どの場合が森林および森林への遷移途 中相や農地であるが，特に河川区域では低木や草 本などの群落で，そのサイズが小さいものが主体 であるため，それぞれの群落を充分把握できるス ケールでの調査や解析が必要になる（Nakagoshi et al., 1998).

これらの背景を踏まえて,今回は, その地域の環 境要素を指標するとともに，それ自体が他の生物
にとっての生育環境となる植物を中心に，広島県 山県郡加計町の温井ダムにおいて進められている 事業後調査を紹介する。またそれを踏まえて,ダム 建設における生態系アセスメントの手法について 検討したい.

\section{温井ダムの概況}

温井ダムは広島県西部を流机る一級河川太田川 水系に属する滝山川に建設されている（図 1)。堤 体の高さ $156 \mathrm{~m}$ のアーチ式コンクリートダムで, 湛 水面積は $1.6 \mathrm{~km}^{2}$, 貯水量は 8200 万 $\mathrm{m}^{3}$ にのぼる。発 電・貯水・洪水調節・レクリエーションなどに利用 される多目的ダムである。1991年に本体工事に着 工，1999年春に堤体が完成し，同年 10 月末より試 験湛水が開始された。国道186号線の一部が水没す るため，1995年に渓谷斜面上部に付け替え国道が 新設された他, 工事, 維持管理, 生活道路としてい

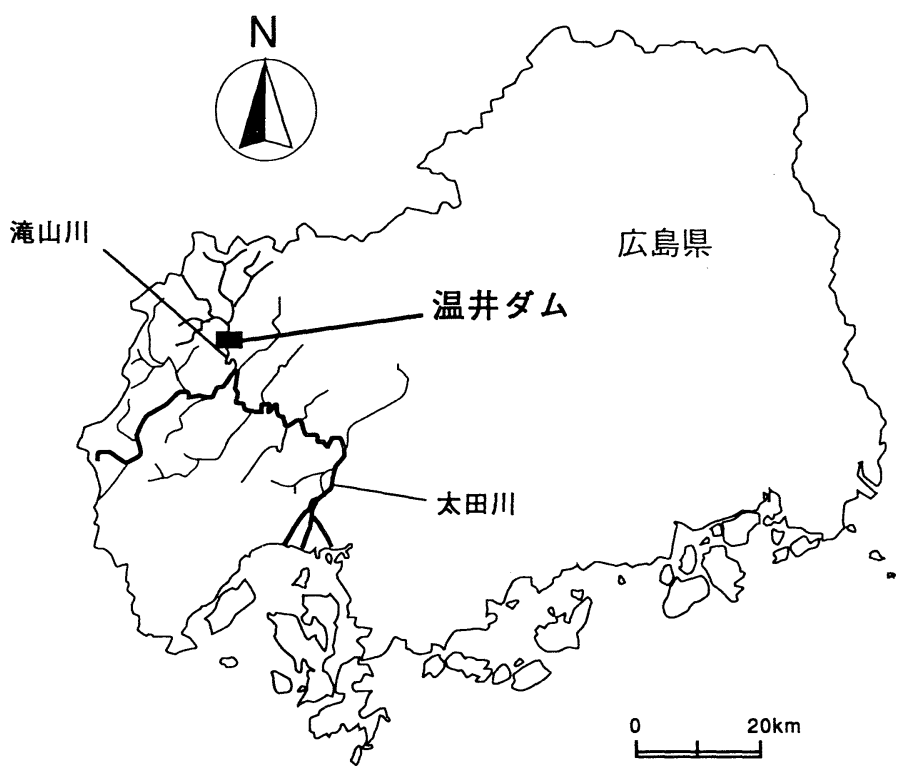

図 1. 調査地 

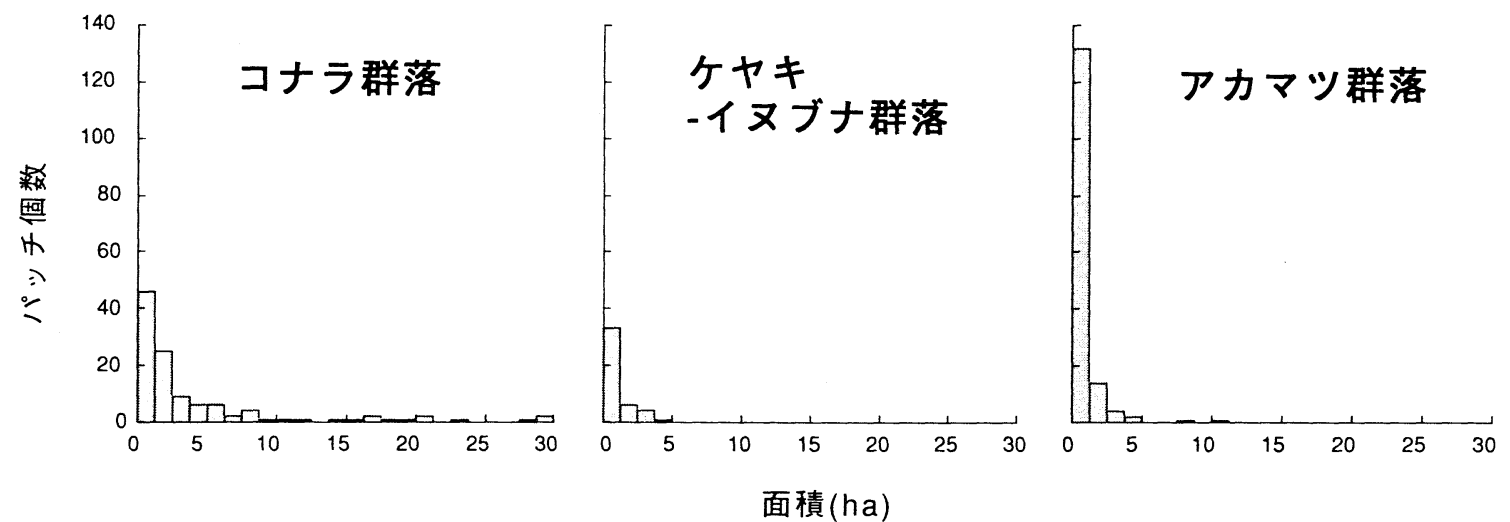

図 2. 温井ダム建設予定地周辺における主要 3 群落のパッチサイズ分布

くつかの町道・林道が建設されている.

\section{陸域における調査・解析}

本調査は1997年から本年度まで, ダム堤体から 周囲の稜線を基準とした調查区域を設定し，植物 を主体として進めた。まず始めにこれまでのアセ スメント調查と同じく, 植物社会学的植生調査, フ ロラ調査, 相観植生図, および樹高により区分した 植生図の作成などを行った。相観植生図のスケー ルは，植物社会学において均一な森林と見なされ る $10 \mathrm{~m} \times 10 \mathrm{~m}$ のサイ゙を最小認識単位（Minimum Mapping Unit）と考え，それが地図上に表現できる 1:10,000を用いた。

データを総合的に解析するためには地理情報シ ステム（Geographic Information System: GIS）を用 いた，GISを使用するメリットとしては，様々な デー夕を統一的に管理でき，二次元あるいは三次 元の空間解析が可能となることが挙げられる．例 えば,新アセス法に基づく評価を行うためには, 主 要な生息環境を類型化する段階でも, 植生・地形· 土地利用などの調査項目を個々の地図として作製・ 評価するのではなく, 様々な主題図を併せて解析 し定量化された形で評価を行うこと,すなわち, 景 観生態学的アプローチが必要となってくる (中越. 日笠, 1999)。しかし収集される情報は, デー夕形 式や調査スケールが様々で, そのままでは相互に 解析するのが難しい．ところが調査結果はすべて 地理情報，すなわち地図上の情報で残すように留 意すればデータの統一が容易になる上, 調査地点 を記録しておけげその後のモニタリングにも有益 である。

まず本調査では，大きな面積を占める三つの自 然群落が典型性群落として挙げられる.GISに入力 した植生図からこの三群落のパッチのサイズ分布
を解析した. 大面積のパッチが多いコナラ群落と, 小面積のパッチが多数存在するアカマッ群落・ケ ヤキーイヌブナ群落が区別される（図2）。またこれ を地形図と併せて解析すると, 同じようなパッチ サイズ分布を示す二群落は, アカマツ群落は尾根 部に,ケヤキーイヌブナ群落は谷部に分布するとい う違いが見えてくる. 本調査では動物のデータが 揃わなかったため行えなかったが，今後は生態系 上位種である大型哺乳類・鳥類などのデータを重 ね合わせることで, それらのハビタットの空間構 造の解析にまで進めることが必要であろう。

さらにこれらのデー夕を用いて，自然性が高く 影響が大きいと思われるケヤキ-イヌブナ群落につ いて, ダム建設に伴って整備された道路によって 個々のパッチが受ける影響度合いを予測評価する 試みを行った。まず, パッチの面積と, 道路と接す る周長の割合によってレベル分けを行い，パッチ が小さいほど，また道路と接する割合が多いほど 影響が大きいと仮定した（図3）。この解析に使用

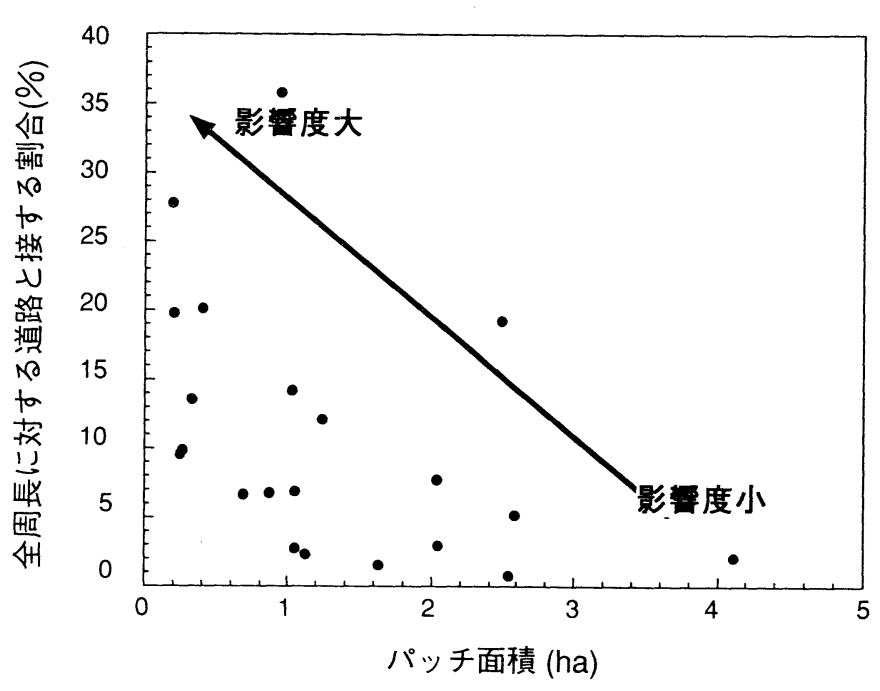

図 3. 道路によるケヤキーイヌブナ群落への影響度評価 
上流部流部

水際で優占するもの

自然裸地

自然裸地

上記の植生型と比べて陸側に存在するもの

ネコヤナギ群落

カワラハンノキ群落

キシツツジ群落
ヌルテ群落

ネコヤナギ群落

キシツツジ群落
下流部

河川の流れ

ツルヨシ群落

水際から離れて存在するもの

ヌルデ群落

ツルヨシ群落
ツルヨシ群落

カワラハンノキ群落
自然裸地

ネコヤナギ群落

ヌルデ群落

図 4. 河川植生の分布変化

したのは植生図と工事区域図だけであるが，これ に地形や土壤などの様々なファクターを加えるこ とによって, 更に詳細な予測も可能だろう.予測し た結果が実際にどのくらい正確かについては今後 のモニタリングによって検証する必要がある。し かしこのような解析を行うメリットとして，モニ タリング地点の設定や検証のための調査項目設定 などの指標が作成できることが挙げられる.

\section{水域における調査・解析}

滝山川は急峻な $\mathrm{V}$ 字渓谷であり, 谷底を流れる 渓流の幅は非常に狭く至る所に岩盤が露出してい るため, 渓畔林は発達せず, 摚乱に適応した低木群 落が形成されている．本区域内で希少種とされる 植物種は, 殆どがこのような渓谷に生育する種で, これらを注目種とする場合, 1:25,000の相観植生図 では, 群落サイズが小さく細長い水域の植生構造 を解析することは出来ない，そこで 1:2,500で河川 区域内のみの植生図を, 現地踏査によって作成し た.このデー夕もすべて GISに入力して解析した. 水域におけるダムによる生態系への影響を予測 する上では, ダム予定地上流と下流の, 現状での地 域的な相違をまず把握しておく必要がある. 日本 では河川構造物が存在しない河川は殆ど存在しな いため，特定のダムによる影響を正確に把握する ためには, 現状分析が非常に重要である.ダムが稼 働する以前の河川の状態を定量的に記録しておけ ば, 何年か後のモニタリングで変化が生じた場合, ダムによるものか自然の擋乱によるものか, 原因
を確認することが出来る。

ダムの上流域と下流域で植物群落の種類や量 · サイズを比較したところ, 各群落の合計面積が異 なるだけでなく（表1），パッチのサイズも異なっ ていた（表2）．水際に接している群落を上流域と 下流域で比較すると，上流域で水際に接していな かった群落でも, 下流域では水際に存在するなど, 同じ群落でも上流と下流で分布する位置が異なる ことが分かる (図4).これらの分布傾向は各群落 の擋乱に対する強度や特性から説明することがで きる.ダムによる流送土砂・水量の变化が下流に及 ほす寸物理的影響については様々な研究が蓄積され ており（辻本，1999）, 湛水後の河川の流量変化や 洪水頻度の变化デー夕を加えることで，下流域に おける今後の群落の変化を予測することも可能た ろう。

\section{5. 今後の課題}

これまでアセスメント調查では, 調査にかける 時間や人員・機材の不足により，そのデータが充分 に解析されているとは言えない. 本報告のように， これまで蓄積されてきたようなデー夕も，充分吟 味して解析すればある程度の予測解析は行うこと が出来ると考える。

また, 新アセス法にからむ様々な議論の中で, 生 態系に対する知見の不足が指摘されている。確か に，モデルを構築したり正確な予測を行えるデー 夕の蓄積は不十分である.従って, まずは出来る範 囲での影響予測を行った上で，モニタリングに 
よって予測の正確さを確認するような仮説検証型 の調査を進めていく必要がある.そのためには, 順 応的管理（敦谷, 1998）の概念を適用するなど，ア セスメントの過程全体の中で調査・解析計画を立 案する必要があるだろう。

\section{引用文献}

環境庁企画調整局（編）. 1999. 自然環境のアセス メント技術(I) 生態系・自然とのふれあい分野の スコーピングの進め方. 358pp. 大蔵省印刷局. 河川事業環境影響評価研究会. 1999. ダム事業に おける環境影響評価の考え方.. 建設省河川局. 中越信和・日笠 睦. 1999. 環境アセスメント法に おける生態系評価手法. 日本緑化工学会誌, 24:
130-136.

Nakagoshi N., Hikasa M., Koarai M., Goda T. and Sakai I. (1998) Grid map analysis and its application for detecting vegetation changes in Japan. Applied Vegetation Science 1: 219-224.

島谷幸宏。2000。環境影響評価におけるダム事業 の生態系の調査 - 予測 - 評価方法. 土木技術資 料, 42(1): 28-31.

辻本哲郎. 1999. ダムが河川の物理的環境に与え る影響 - 河川工学および水理学的視点から -. 応 用生態工学, 2(2): 103-112.

熟谷いづみ. 1998. 生態系管理における順応的管 理. 保全生態学研究, 3: 145-166. 